\title{
PEMBERDAYAAN MASYARAKAT MELALUI PENGELOLAAN LIMBAH ORGANIK RUMAH TANGGA DALAM PEMBUATAN KOMPOS
}

\section{COMMUNITY EMPOWERMENT THROUGH HOUSEHOLD ORGANIC WASTE MANAGEMENT IN COMPOS MAKING}

\author{
Meri Enita Puspita Sari ${ }^{1 *}$, Diah Ayu Pratiwi² dan Sri Mulyati ${ }^{3}$ \\ ${ }^{12}$ (Prodi Ilmu Pemerintahan, Universitas Riau Kepulauan) \\ 3 (Prodi Akutansi, Universitas Riau Kepulauan) \\ 1merienitaps@gmail.com;diah_mahdan@yahoo.co.id; sri@fe.unrika.ac.id
}

\begin{abstract}
Abstrak
Di Indonesia,permasalahan lingkungan diperkotaan menjadi salah satu sorotan dalam pelestarian lingkungan, kurangnya ruang hijau dan pengelolaan limbah organik darilimbah rumah tangga yang kurang tepat menjadi salah satu sumber masalah di perkotaan yang akan menimbulkan berbagai bencana misalnya banjir dan polusi. Beberapa kota di Indonesia telah mengembangkan program yang ramah terhadap lingkungan sebagai upaya menjaga keberlanjutan lingkungan. Oleh karena itu, pengelolaan limbah organik dan limbah rumah tangga dengan benar dapat memberikan kontribusi yang besar dalam pelestarian lingkuangan, baik dari segi penghijauan ataupun pengurangan sampah yang dihasilkan oleh rumah tangga yang pada dasarnya bisa dikelola menjadi kompos.Pembuatan kompos ini mampu memberikan kontibusi terhadap kebutuhan masyarakat dalam bercocok tanam walaupun didaerah patam lestari.Kegiatan pembuatan kompos telah membangun masyarakat untuk bersosialisasi dalam bercocok tanam, Dalamkegiatan ini langkah yang diambil untuk pembuatan kompos dari sisa-sisa limbah rumah tangga berupa sampah organik. Dari kegiatan pengabdian ini masyarakat Patam Lestari dapat memanfaatkan limbah rumah tangga berupa sampah olahan organik yang ada nilai fungsinya.
\end{abstract}

Kata Kunci :Kompos, Limbah organik,Pelestarian Lingkungan

\begin{abstract}
In Indonesia, urban environmental problems become one of the highlights in environmental preservation, the lack of green space and improper management of organic waste from household waste is one source of problems in urban areas that will cause various disasters such as floods and pollution. Several cities in Indonesia have developed programs that are friendly to the environment in an effort to maintain environmental sustainability. Therefore, the proper management of organic waste and household waste can contribute greatly to environmental preservation, both in terms of greening or reducing waste generated by households which can basically be managed to become compost. Making compost is able to contribute to the needs of the community in farming even in the Patam Lestari. Composting activities have built the community to socialize in farming. In this activity, steps were taken to make composers from the remnants of household waste in the form of organic waste. This community dedication, the Patam Lestari community can utilize household waste in the form of processed organic waste that has a functional value.
\end{abstract}

Keywords : Compost, Organic Waste, Environmental Conservation

\section{PENDAHULUAN}

Permasalahan pencemaran lingkungan hidup disebabkan terutama perilaku manusia yang tidak mengelola limbah dan sampah dari aktivitasnya secara benar (Asrul, 2010). Meskipun sampah seringkali menjadi masalah, namun tak dapat dipungkiri bahwa 
adanya sampah dapat dijadikan sebagai tanda-tanda kehidupan dan perekonomian masyarakat di sekitarnya. Pengolahan sampah secara sederhana bisa dimulai dari mengumpulkan sampah, memilah sampah, mencacah sampah menjadi bagian-bagian yang lebih kecil, sampai pada proses pembusukan secara aktif maupun pasif, hingga menjadikannya berubah dan memiliki nilai ekonomis bagi masyarakat sekitarnya.Sampah organik dari sisa makanan, kotoran ternak, dedaunan dan rumput, dapat diproses untuk menjadi pupuk kompos. Gas yang dihasilkan dari dalam sampah juga dapat digunakan untuk memenuhi kebutuhan bahan bakar. Penelitian menyebutkan, bila dalam satu rumah tangga memelihara dua ekor sapi, maka biogas yang dihasilkan dari kotoran sapi itu cukup untuk memenuhi kebutuhan bahan bakar untuk memasak selama satu bulan (ITB, 12 Oktober 2016).

Semakin meningkatnya jumlah penduduk akan menimbulkan berbagai permasalahan sendiri mulai dari masing-masing individu sampai dengan industri besar yang menghasilkan limbah industri (Diah, 2017).Salah satu masalah yang timbul akibat limbah dan sampah yaitu banjir (Ali, 2019).Bisa kita lihat dari bencana alam berupa banjir akibat sampah yang dihasilkan oleh rumah tangga.Sampah-sampah tersebut dapat menghalangi aliran air di selokan, terutama saat musim hujan di mana intensitas air hujan sangat tinggi.Tidak hanya itu, sampah yang menumpuk juga mampu memperburuk keadaan dan kualitas lingkungan di masyarakat sehingga dapat menimbulkan penyakit.Melihat keadaan tersebut dapat disimpulkan bahwa sampah merupakan konsekuensi dari berbagai aktivitas yang dilakukan manusia.Volume sampah yang merupakan hasil pembuangan rumah tangga semakin bertambah seiring dengan makin tinggi aktivitas yang dilakukan dan bertambahnya kebutuhan masyarakat yang semakin modern. Sampah dapat dikategorikan berdasarkan berbagai jenis, tergantung material yang dikonsumsi. Sampah menjadi isu lingkungan yang besar terutama apabila pengelolaan sampah tidak dilakukan secara benar maka akan berdampak buruk bagi lingkungan (Gabriella, 2017).

Pengelolaan limbah organik dari limbah rumah tangga dengan benar dapat memberikan manfaat yang besar, baik dari segi menghemat energi, mengurangi polusi dan bernilai ekonomis (DLH Semarang, 02 Agustus 2017).Tujuan dari kegiatan pemberdayaan ini agar masyarakat lebih peduli terhadap lingkungan dan memiliki keterampilan dalam pembuatan kompos, sehingga dapat membantu dalam mengurangi produksi sampah dan limbah rumah tangga yang dapat mengakibatkan masalah kesehatan, bencana banjir dan masalah lingkungan lainnya. 


\section{METODOLOGI}

Kegiatan “Pemberdayaan Masyarakat Melalui Pengelolaan Limbah Organik Rumah Tangga Dalam Pembuatan Kompos”dilaksanakan pada bulan Agustus 2019bertempat di RW 01, Kelurahan Patam Lestari, Kecamatan Sekupang, Kota Batam.Bentuk kegiatan pemberdayaan ini dilakukan dengan pendekatan sosialisasi dan pelatihan. Sosialisasi merupakan tahapan awal yang dilaksanakan dengan pemberian materi dengan disampaikan langsung ke warga yang menjadi peserta pelatihan sehingga ada interaksi timbal balik berupa diskusi dan tanya jawab. Selanjutnya, kegiatan pelatihan disampaikan melalui praktek langsung yang diawali dengan pemberian materi disertakan praktek secara bersamaan dengan maksud agar warga bisa lebih cepat memahami dengan metode ini, praktek dilaksanakan dengan menyiapkan media pembuatan kompos, proses pembuatan hingga kompos dihasilkan.

\section{HASIL DAN PEMBAHASAN}

Kegiatan pembuatan kompos ini dilaksanakan melalui sosialisasi dan praktek pembuatan kompos yang langsung disampaikan kepada warga RW 1 kelurahan Patam Lestari.Warga yang menjadi peserta dalam kegiatan ini sebagian besar adalah ibu-ibu rumah tangga dan beberapa perangkat RT dan RW yang ikut hadir.Warga sangat antusias dan fokus dalam mengikuti kegiatan sampai selesai.Kegiatan ini mendorong masyarakat untuk dapat mengelola sampaah organik untuk dijadikan kompos.Kompos sebagai salah satu pupuk organik sangat baik dan bermanfaat untuk segala jenis tanaman.Pupuk ini digunakan untuk tanaman pangan, tanaman perkebunan, tanaman pertanian, dan bahkan tanaman hias.Hanya dengan menaburkannya di permukaan tanah, maka sifat-sifat tanah yang baik dapat dipertahankan bahkan ditingkatkan lagi (Nurul, 2019).

\section{Sosialisasi Kegiatan}

Sosialisasi kegiatan pembuatan kompos diawali dengan pemberian materi, materi yang diberikan berisi tentang manfaat dari pembuatan kompos dan tata cara pembuatan kompos, dan limbah organik. Materi disampaikan secara lisan dengan bahasa yang sederhana yang dapat dipahami oleh warga dan diselingi dengan sesi tanya jawab. Selain itu materi disampaikan juga menggunakan power point yang berisi gambar dan video proses pembuatan kompos. Selama proses sosialisasi berlangsung, warga sangat tertarik dan antusias dalam melihat penyampaian materi yang ditampilkan. Proses sosialisasi berjalan lancer dan diskusi 
yang terjadi selama proses sosialisasi mampu memberikan motivasi dan pemahaman bagi warga terhadap pembuatan kompos tersebut.

Secara khusus kegiatan sosialisasi di isi dengan materi tentang : 1) Penjelasan tentang limbah organik Rumah tangga, 2) Penjelasan tentang Kompos, 3) Penjelasan tentang pengelolaan limbah dalam pembuatan kompos.

\section{Persiapan Kegiatan}

Persiapan di lakukan dimulai dari penyedian alat yang berupa ember, bor yang berfungsi untuk membuat lobang pada ember yang akan dibuat kompos, gergaji berfungsi untuk memotong paralon, spidol berfungsi untuk memberi tanda pada bolongan, keran air dan pelster untuk memanen kompos cair yang dihasilkan, meteran, gunting, paralon dan fiber berfungsi sebagai alas dan saringan bahan kompos. Selanjutnya disediakan tanah dan sampah organik.
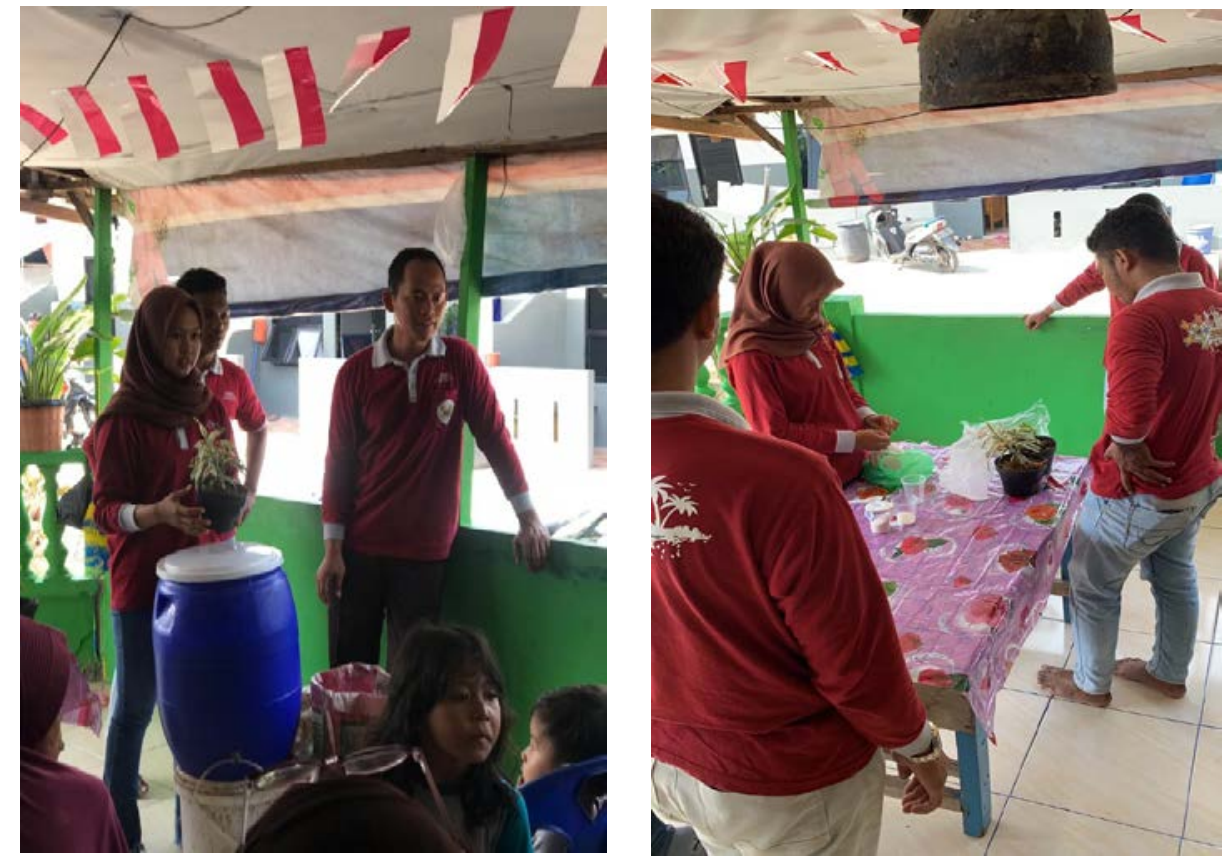

Figur 1. Persiapan alat dan bahan praktek

\section{Proses pembuatan Kompos}

Dalam proses pembuatan kompos harus disampaikan dan ditanamkan diawal kepada warga bahwa pembuatan kompos ini bukan sesuatu yang rumit. Disamping itu, alat dan bahan yang dibutuhkan selalu ada disekitar rumah warga.Dalam proses pembuatan kompos dilakukan dengan praktek langsung agar warga lebih cepat memahami proses pembuatannya. Proses pembuatan kompos dilakukan bersama-sama dengan warga melalui tahapan: 
1. Penyiapkan sampah rumah tangga yang akan diolah menjadi pupuk kompos. Sampah yang digunakan dalam kegiatan ini langsung dipilih dari sampah organik yang ada di warga agar warga bisa langsung melihat dan memilah sampah organik dan sampah non organik.

2. Setelah sampah organik terkumpul, masukkan tanah secukupnya ke dalam wadah yang telah diisi dengan sampah organik dan siram permukaan tanah tersebut menggunakan air secukupnya.

3. Proses selanjutnya dengan memasukkan sampah organik yang sudah disiapkan ke dalam wadah yang berisi tanah dengan tingkat ketebalan sampah dan tanah setara. Setelah itu tutup kembali dengan tanah dan tinggal menunggu sampah terurai dan menjadi kompos selama lebih kurang 1 minggu.

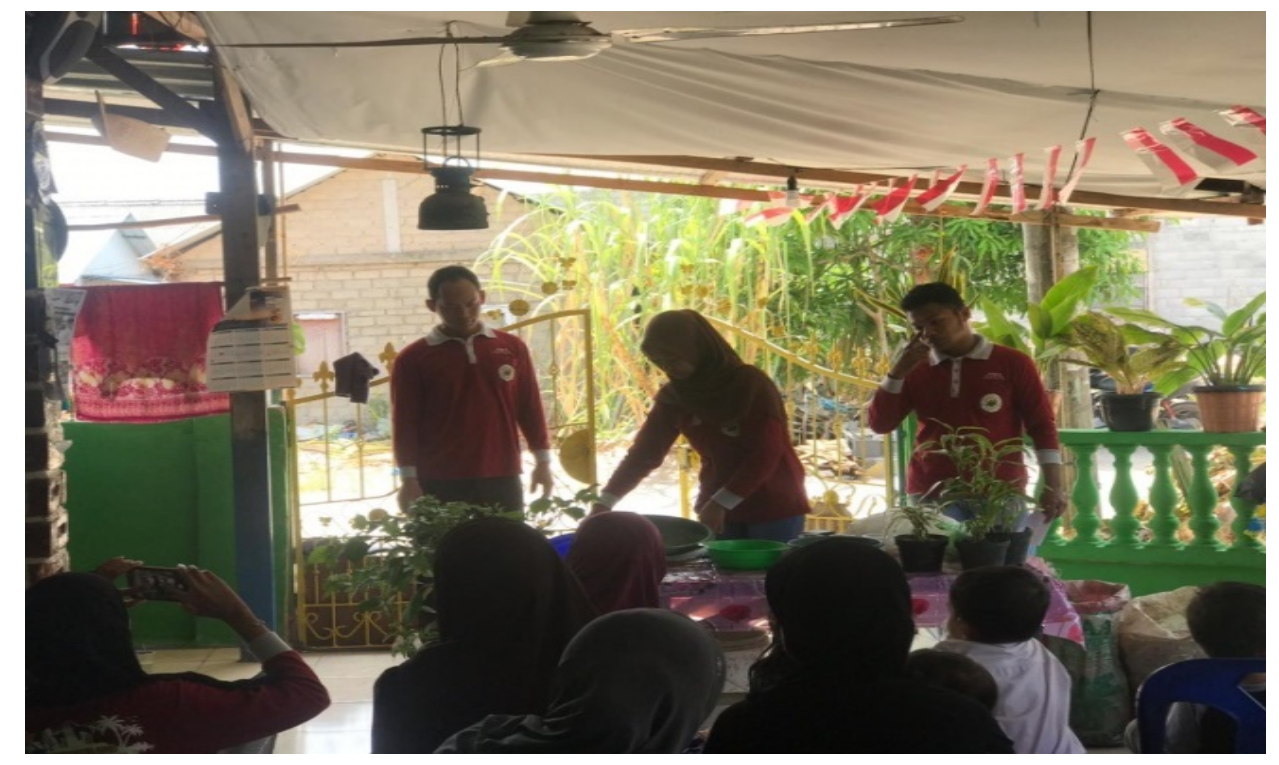

Figur 2. Proses Pembuatan Kompos

Proses pembuatan kompos ini berjalan dengan lancar, praktek dilaksanakan bersamasama dengan warga. Warga atau peserta kegiatan tidak hanya melihat proses pembuatan kompos yang di praktekan pemateri saja, tapi langsung melakukan mulai dari tahap persiapan sampai pembuatan. Diskusi dan tanya jawab tetap berjalan di sela-sela proses pembuatan kompos. Dalam proses ini, warga diajarkan tentang memilah sampah organik dan non organik dan memberikan nilai tambah yang dapat menambah penghasilan keluarga untu keperluan kehidupan sehari-hari. 


\section{Kegiatan Tanya Jawab antara tim pengabdian dan warga}

Kegiatan tanya jawab dilaksanakan dengan 2 sesi, diantaranya 1 sesi terdapat 3 pertanyaan dari 3 orang dan sesi ke 2 dilanjutkan dengan 3 pertanyaan selanjutnya dari warga. Tanya jawab ini bertujuan agar warga yang belum mengerti bisa menanyakan kembali langkah-langkah dalam pembuatan kompos agar tidak terjadi kekeliruan dalam pembuatan kompos kedepannya.

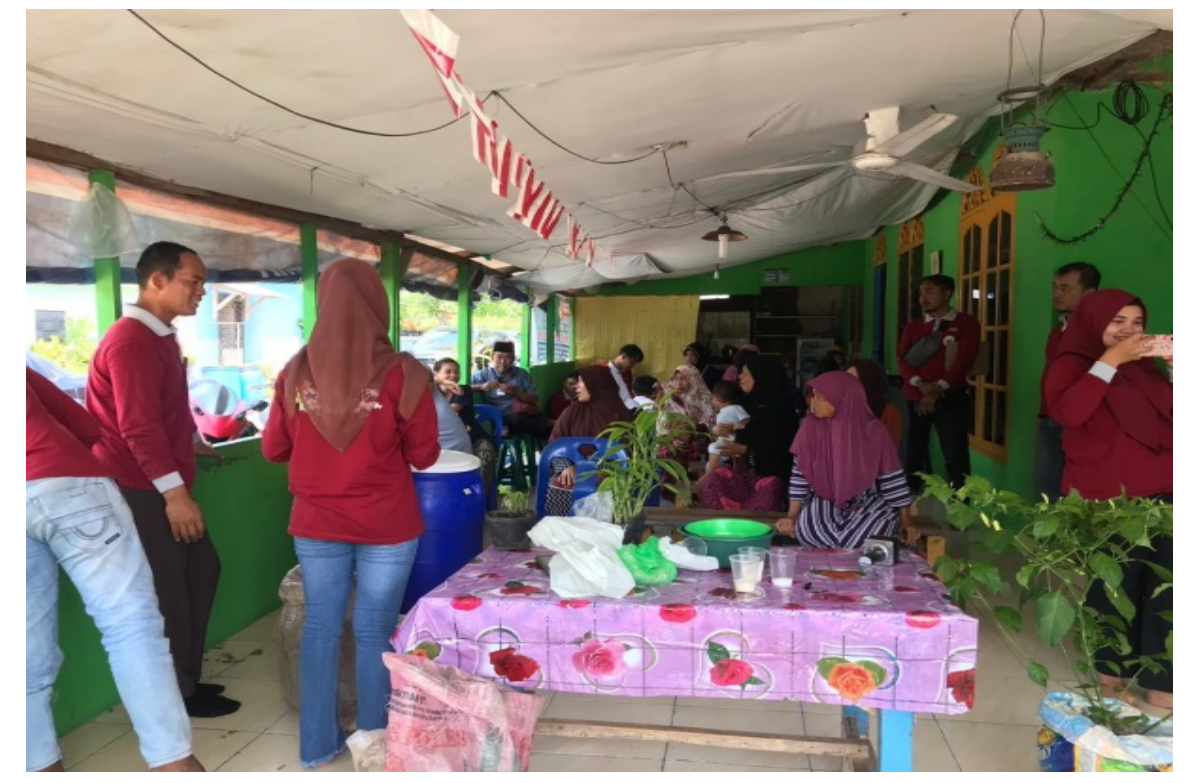

Figur 3.Kegiatan diskusi dan tanya-jawab

Masyarakatdi kelurahan patam lestari sangat antusias terhadap kegiatan pelatihan ini.Dengan adanya Pelatihan Pembuatan Kompos, masyarakat RW 01 Kelurahan Patam Lestari telah memahami dan mengetahui langkah pembuatan komposdengan baik dan benar dengan memanfaatakan limbah rumah tangga. Dari hasil pemanfaatan pengelolaan limbah rumah tangga, bukan hanya ramah lingkungan, tetapi juga memiliki nilai fungsi ekonomis (DLH Semarang, 02 Agustus 2017).

Hasil yang didapatkan setalah pelatihan pembuatan kompos ini, masyarakat bisa mengelolah sampah organik dan sampah rumah tangga yang setiap hari dihasilkan oleh masing-masing rumah tangga itu, untuk dipergunakan sebagai bahan baku pembuatan kompos yang dapat dimanfaatkan untuk tanaman-tanaman yang ada disekitar rumah dan juga sangat bermanfaat terhadap kebersihan lingkungan. 


\section{KESIMPULAN DAN SARAN}

Setelah melakukan kegiatan pembuatan Kompos, masyarakat lebih peduli terhadap lingkungan dan memiliki keterampilan dalam pembuatan kompos, sehingga dapat membantu dalam mengurangi produksi sampah dan limbah rumah tangga yang dapat mengakibatkan masalah kesehatan dan bencana banjir. Berdasarkan kesimpulan tersebut disarankan waktu pelaksanaan pembuatan kompos perlu diperhatikan mengingat waktu yang dibutuhkan cukup lama sampai hasil yang didapatkan tergantung dengan bahan dan metode yang digunakan.

\section{REFERENSI}

Dinas Lingkungan Hidup Kota Semarang. (2017). 5 Manfaat Pengelolaan Sampah yang Baik.02 Agustus 2017. https://dlh.semarangkota.go.id/5-manfaat-pengolahan-sampahyang-baik/

Efendi, A. (2019). Gangguan Sampah dalam Bencana Banjir. 29 April 2019. https://www.kompasiana.com/ali38116/5cc6d034a8bc1536ec083f1c/gangguansampah-dalam-bencana-banjir?page $=2$

Gebby, G. (2017). Gaya Hidup Riset Penelitian Pengelolaan Limbah Sampah Rumah Tangga.3 Desember 2017. https://www.kompasiana.com/gebby/5a240ee2cf78db $\underline{5782773122 / \text { riset-penelitian-pengolahan-limbah-sampah-rumah-tangga?page=all }}$

Hoesein, A. (2010). Sampah Menjadi Masalah Serius Perkotaan. 27 November 2010.https://www.kompasiana.com/hasrulhoesein/55004a2ca333115263511214/samp ah-menjadi-masalah-serius-perkotaan?page=all

ITB Kampus Jatinangor.(2016). Pelatihan Pembuatan Pupuk Kompos, Menjadikan Sampah Organik Bernilai Ekonomis Bagi Masyarakat Desa di Kecamatan Jatinangor.12 Oktober 2016. https://jatinangor.itb.ac.id/pelatihan-pembuatan-pupuk-kompos/

Pratiwi, D. A. (2017). Pemberdayaan Masyarakat RW. 12 dalam Kegiatan Penghijauan Lingkungan di Kav. Mandiri, Kelurahan Sei Pelunggut. Jurnal Minda Baharu, Vol. 1(1): 25-32.

Ramadhani, N. A. (2019). Kompos : Pengertian, Jenis, Manfaat, Bahan, Kualitas, dan Pembuatan. 20 Juni 2019. https://foresteract.com/kompos/ 